\title{
PENGARUH ASAL DAERAH DAN JUMLAH AKUN ONLINE SHOP TERHADAP POLA HIDUP KONSUMTIF MAHASISWA
}

\author{
${ }^{1)}$ Yulianti*, ${ }^{2)}$ Ekawati Dewi, ${ }^{3)}$ Baiq Rika Ayu Febrilia \\ 1,2,3) Universitas Pendidikan Mandalika \\ ${ }^{1)}$ yuliyanti010100@gmail.com, ${ }^{2)}$ dewiekhawati@gmail.com, ${ }^{3)}$ rikafebrilia@ikipmataram.ac.id
}

\begin{abstract}
Received: 07/02/2020

Accepted :

07/07/2020

Published :

11/07/2020

Abstract

The development of an increasingly modern era, resulting in changes in people's lifestyles that change, so that the consumptive pattern of society is increasing. Thus, researchers conducted a study on this subject which aims to analyze the factors that influence the consumptive lifestyle of students by using ordinal logistic regression analysis. The focus of the factors observed was regional origin and the number of online shop accounts. Data collection was carried out using an online Google survey form sheet from Mandalika University Education students in one faculty of 100 people. The results showed that the influencing factor significantly came from the variable number of online shop accounts.
\end{abstract}

Keywords: ordinal logistic regression, factors, consumptive lifestyle

\begin{abstract}
Abstrak
Adanya perkembangan zaman yang semakin modern, mengakibatkan perubahan gaya hidup masyarakat yang berubah, sehingga pola konsumtif masyarakat semakin meningkat. Dengan demikian, peneliti melakukan sebuah penelitian mengenai hal ini yang bertujuan untuk menganalisis faktor-faktor yang mempengaruhi pola hidup konsumtif mahasiswa dengan menggunakan analisis regresi logistik ordinal. Fokus faktor yang diamati adalah asal daerah dan banyaknya akun online shop. Pengumpulan data dilakukan dengan menggunakan lembar survey online Google Form dari mahasiswa Universitas Pendidikan Mandalika pada salah satu fakultas sebanyak 100 orang. Hasil penelitian menunjukkan bahwa faktor yang mempengaruhi secara signifikan berasal dari variabel banyaknya akun online shop.
\end{abstract}

Kata Kunci: regresi logistik ordinal, faktor-faktor, pola hidup konsumtif

\section{Pendahuluan}

Perilaku konsumtif merupakan suatu tindakan yang menggunaan suatu produk secara berlebihan, keinginan untuk tampil berbeda dari orang lain. Perilaku konsumtif cenderung boros karena lebih mementingkan keinginan yang terpenuhi dari pada manfaat dari barang tersebut (Astuti, 2013). Perilaku konsumtif cenderung mendorong seseorang untuk memiliki barang atau jasa yang memiliki harga di atas rata-rata untuk kepuasan semata, mendapatkan barang yang lebih bagus, tetapi tujuan utama membeli barang atau jasa tersebut hanya untuk menunjukkan status sosial keluarganya, dan kekayaan yang dimiliki (Suminar \& Meiyuntari, 2015).

Perubahan gaya hidup mahasiswa tidak lepas dari perkembangan teknologi yang ada, perkembangan dari masa kemasa membuat mahasiswa memiliki gaya tersendiri dalam hal gaya hidup, serta pengaruh dari internet terhadap penampilan (Novitasani, 2014). Media sosial bagian dari internet (Kaplan \& Haenlin, 2010), sedangkan online shop adalah salah satu ide yang muncul atas keberadaan media sosial dan internet. Online shop atau belanja via internet adalah suatu proses jual beli yang dilakukan dengan secara online (melalui media internet) yang mana antara penjual dan pembeli tidak bertemu secara langsung. Online shop menjadi salah satu pilihan favorit bagi 
masyarakat masa kini terutama di kalangan mahasiswa karena mereka tidak perlu menghabiskan tenaga untuk membeli barang dan membandingkan harga barang tersebut ke toko-toko.

Mereka dapat memperoleh segala informasi hanya dengan satu sentuhan tombol. Selain itu, online shop menawarkan harga yang cukup bersaing dengan harga toko pada umumnya, kerap mengadakan berbagai promo, diskon dan fitur gratis ongkos kirim yang pada akhirnya lebih menarik minat para pembeli (Miranda \& Lubis, 2017). Online shop tidak hanya sekedar berbelanja tetapi juga bagian dari perubahan sosial budaya pada masyarakat (Sari, 2015). Dengan adanya online shop dan membuat akun dalam online shop tersebut, mahasiswa dapat secara bebas memantau perkembangan gaya hidup masa kini dan mengikutinya. Pada akhirnya gaya hidup atau perilaku mereka juga akan terpengaruh baik secara langsung maupun tidak langsung.

Perilaku konsumtif juga dapat dipengaruhi oleh status sosial keluarga dan juga lingkungan seseorang itu tinggal (Dewi \& Rusdarti, 2017). Perubahan gaya hidup mahasiswa yang berasal dari desa sering terpengaruh oleh lingkungan dan temannya baik itu teman yang berada pada kampus atau pun tempat tinggal yang baru (Sari, 2017). Perkembangan suatu daerah tidak bisa lepas dari kalangan pelajar, di mana mahasiswa menjadi faktor perubahan, misalnya mahasiswa berada pada golongan terpelajar maka secara tidak langsung dapat menunjukkan status sosialnya, dengan gaya hidup, perubahan gaya dari tempat tinggal desa menuju tempat tinggal kota akan berbeda, misalnya sebelum tinggal di kota tidak terlalu mengenal tempat nongkrong, tidak keluar pada malam hari, maka ketika tempat tinggal mereka berubah dari desa ke kota otomatis gaya hidup orang tersebut berbeda mulai dari penampilannya hingga gaya berbicaranya, selain itu kondisi lingkungan yang ada di kampus berbeda dengan asal daerah tempat tinggal mereka dulu serta tempat tinggal yang ditempati ketika menempuh pendidikan yang membebaskan dalam hal bertindak juga dapat merubah kebiasaan seseorang (Sari, 2017). Oleh karena itu dapat disimpulkan bahwa selain banyaknya akun online shop, daerah asal tempat tinggal juga mempengaruhi pola hidup konsumtif seseorang khususnya mahasiswa.

Pengaruh faktor-faktor terhadap variabel tertentu dapat dianalisis menggunakan analisis regresi (Fatonah, Sanapiah \& Febrilia, 2017; Febrilia, Rahayu, Korida, 2019). Regresi logistik dapat digunakan untuk varibel respon memiliki sifat kategorik dengan varibel prediktor yang kontinu (Fitriah, Mashuri \& Irhamah, 2012) dengan model logit

$$
\operatorname{Logit} \psi j=\ln \left[\frac{P\left(Y \leq j \mid X_{i}\right)}{P\left(Y>j \mid X_{i}\right)}\right]=\alpha_{j}+\sum_{k=1}^{p} \beta_{k} x_{i k}
$$

di mana $\mathrm{j}=0,1,2, \ldots, \mathrm{j}-1$ dimana $\mathrm{j}$ adalah banyaknya variabel respon dan $\mathrm{k}$ banyak variabel prediktor.

Hal ini bertujuan untuk menganalisis faktor-faktor yang mempengaruhi pola hidup konsumtif pada mahasiswa Universitas Pendidikan Mandalika dengan fokus faktor yang diamati adalah asal daerah dan banyaknya akun online shop yang dimiliki oleh mahasiswa melalui analisis regresi logistik ordinal. Penelitian ini diharapkan dapat menjadi salah satu referensi dalam menggunakan analisis regresi logistik untuk mengamati hubungan sebab akibat antara dua atau lebih variabel. 


\section{Metode Penelitian}

Jenis data yang digunakan adalah data kualitatif. Data yang digunakan adalah data primer mengenai pola hidup konsumtif, daerah asal dan banyak akun online shop dari sampel terdiri atas 100 mahasiswa salah satu fakultas di Universitas Pendidikan Mandalika. Sampel tersebut dipilih secara acak dan diminta untuk mengisi kuesioner yang disebar melalui WhatsApp.

Adapun variabel yang digunakan dalam penelitian adalah pola hidup konsumtif sebagai variabel respon kemudian daerah asal dan jumlah akun online shop yang digunakan sebagai variabel bebas. Variabel respon atau variabel pola hidup konsumtif dalam penelitian menggunakan lima kategori yang sudah ditentukan sebagai berikut.

$$
\begin{aligned}
& 1=\text { sangat tinggi }(25,505<X) \\
& 2=\text { tinggi }(19,835<X \leq 25,505) \\
& 3=\text { sedang }(14,165<X \leq 19,835) \\
& 4=\text { rendah }(8,495<X \leq 14,165) \\
& 5=\text { sangat rendah }(X \leq 8,495)
\end{aligned}
$$

Variabel bebas daerah asal sebagai $\mathrm{X}_{1}$ memiliki dua kategori yang digunakan, yaitu sebagai berikut.

$$
\begin{aligned}
& 1=\text { Kota Mataram } \\
& 2=\text { Luar Kota Mataram }
\end{aligned}
$$

Sedangkan variabel jumlah akun online shop sebagai $\mathrm{X}_{2}$ terdiri dari tiga kategori sebagai berikut.

$$
\begin{aligned}
& 1=1 \text { akun } \\
& 2=2 \text { akun } \\
& 3=>2 \text { akun }
\end{aligned}
$$

Analisis dilakukan menggunakan model regresi logistik ordinal mengingat variabel respon dan prediktornya terdiri atas beberapa kategori dan yang diamati adalah hubungan sebab akibat. Estimasi parameter model regresi logistik ordinal dengan menggunakan Maximum Likelihood Estimator (MLE) menggunakan nilai estimasi $\beta$, jika I adalah sampel dari populasi maka bentuk umum dari likelihood adalah

$$
\mathrm{l}(\beta)=\prod_{\mathrm{i}=1}^{\mathrm{n}}\left[\pi_{0}\left(\mathrm{x}_{\mathrm{i}}\right)^{\mathrm{y} 0 \mathrm{i}} \pi_{1}\left(\mathrm{x}_{\mathrm{i}}\right)^{\mathrm{y} 1 \mathrm{i}} \pi_{2}\left(\mathrm{x}_{\mathrm{i}}\right)^{\mathrm{y} 2 \mathrm{i}}\right]
$$

dimana $I=1,2, \ldots$, n. maka didapatkan ln-likelihood jadi

$$
\mathrm{L}(\beta)=\sum_{\mathrm{i}=1}^{\mathrm{n}}\left[\mathrm{y}_{0 \mathrm{i}} \ln \left(\pi_{0}\left(\mathrm{x}_{\mathrm{i}}\right)\right)+\mathrm{y}_{1 \mathrm{i}} \ln \left(\pi_{1}\left(\mathrm{x}_{\mathrm{i}}\right)\right)+\mathrm{y}_{2 \mathrm{i}} \ln \left(\pi_{2}\left(\mathrm{x}_{\mathrm{i}}\right)\right)\right]
$$

Uji kesesuaian model dengan hipotesis

$\mathrm{H}_{0}$ : model sesuai

$\mathrm{H}_{1}$ : model tidak sesuai

Dapat diujikan dengan cara

$$
D=-2 \sum_{i=1}^{n}\left[y_{0 i} \ln \left(\frac{\pi^{{ }_{i j}}}{y_{i j}}\right)+\left(1-y_{i j}\right) \ln \left(\frac{1-\hat{\pi}^{\hat{i j}_{j}}}{1-y_{i j}}\right)\right]
$$


dengan

$\hat{\pi_{i j}}=\pi^{\wedge}\left(x_{i}\right)$
adalah peluang dari observasi ke- $\mathrm{i}$ untuk ke-j, daerah penolak Ho jika $D>\chi^{2}(\mathrm{df}, \alpha)$

dengan derajat bebas untuk uji ini adalah $\mathrm{J}-(\mathrm{k}+1)$, maka J merupakan jumlah kavariat dan $\mathrm{k}$ jumlah variabel prediktor, jika nilai deviance semakin besar tau semakin kecil maka nilai p-value terdapat kemungkinan nilainya tidak sesuai dengan data.

\section{Hasil dan Pembahasan}

Dapat dilihat bahwa pola hidup komsuntif yang terjadi yang terjadi pada mahasiswa universitas Pendidikan mandalika terbanyak terbanyak masuk dalam kategori sangat rendah dengan persentase sebesar 55\%, Persentase dengan kategori rendah dan sedang masing-masing 36\% dan 9\% dan persentase dengan kategori tinggi dan sangat tinggi tidak tertera. Analisis pola hidup konsumtif mahasiswa dapat dilihat pada Tabel 1, yang mana hasil pada tabel didapatkan melalui perhitungan dari kategori variabel $\mathrm{X}$ diantaranya kategori daerah asal dan jumlah akun yang digunakan. Dari perhitungan tersebut, mahasiswa dengan pola hidup konsumtif.

Tabel 1. Persentase Pola Hidup Konsumtif Mahasiswa.

\begin{tabular}{lc}
\hline \hline Kategori & Persentase \\
\hline Sangat tinggi & $0 \%$ \\
Tinggi & $0 \%$ \\
Sedang & $9 \%$ \\
Rendah & $36 \%$ \\
Sangat Rendah & $55 \%$ \\
\hline
\end{tabular}

Pola hidup konsumtif mahasiswa berada pada kategori rendah karena mahasiswa termasuk dalam kategori masyarakat menengah ke bawah, sehingga mereka hanya membeli keperluan sehari-hari yang bersifat pokok saja (Gumulya \& Widiastuti, 2013), menyatakan bahwa semakin bawah harga diri remaja, maka semakin tinggi pola konsumtifnya sebaliknya semakin tinggi harga diri maka semakin rendah pola konsumtifnya (Suminar \& Maiyuntari, 2015), serta faktor kelas social, keluarga, kelompok bermain dan kelompok social dan faktor internal yaitu faktor motivasi, apresiasi dalam belajar, temperamen serta kebijakan menjadi konsumen.

Data mengenai bagaimana pola hidup konsumtif mahasiswa berdasarkan setiap variabel prediktornya dapat dilihat Tabel 2 dan 3.

Tabel 2. Karakteristik Variabel $Y$ Berdasarkan Asal Daerah.

\begin{tabular}{ccccccc}
\hline \hline X1 & $\begin{array}{c}\text { Sangat } \\
\text { Tinggi }\end{array}$ & Tinggi & Sedang & Rendah & $\begin{array}{c}\text { Sangat } \\
\text { Rendah }\end{array}$ & Total \\
\hline $\begin{array}{c}\text { Kota Mataram } \\
\text { Luar Kota } \\
\text { Mataram }\end{array}$ & $0(0 \%)$ & $0(0 \%)$ & $0(0 \%)$ & $5(33 \%)$ & $10(67 \%)$ & $15(100 \%)$ \\
\hline
\end{tabular}


Tabel 2 menjelaskan bahwa karakteristik pola hidup konsumtif terhadap asal daerah dengan persentase terbesar masuk dalam kategori sangat rendah pada mahasiswa yang berasal dari luar Kota Mataram yaitu 53\% atau sebanyak 45 dari 85 mahasiswa, sedangkan kategori rendah dengan persentase 36\% atau sebanyak 31 dari 85 mahasiswa dan kategori sedang dengan persentase $10 \%$ atau sebanyak 9 dari 85 mahasiswa. Untuk mahasiswa yang berasal dari Kota Mataram, persentase pola hidup konsumtif tertinggi masuk dalam kategori sangat rendah yaitu 67\% atau sebanyak 10 dari 15 mahasiswa diikuti dengan kategori sangat rendah. Menariknya, mahasiswa dengan pola hidup konsumtif pada kategori sedang muncul dari mahasiswa yang berasal dari luar Kota Mataram, sedangkan mahasiswa yang berasal dari dalam kota Mataram hanya di posisi rendah dan sangat rendah. Hal ini dikarenakan adanya proses urbanisasi,

Urbanisasi artinya proses perpindahan warga desa kecil ke kota (Zaman, 2017). Mahasiswa urbanisasi ini biasanya memiliki gaya konsumtif yang berbeda dengan masyarakat asli perkotaan, seperti melakukan kegiatan berbelanja terlalu sering, perubahan cara berpakaian dari yang sederhana menjadi lebih modis (Novitasani \& Handoyo, 2014), adanya persaingan gaya hidup dengan orang lain (Zaman, 2017). Hal ini diakibatkan oleh kehidupan kota Mataram yang sangat modern dibanding dengan tempat yang lain.

Tabel 3. Karakteristik Variabel Y Berdasarkan Jumlah Akun Online Shop.

\begin{tabular}{ccccccc}
\hline \hline \multirow{2}{*}{ X2 } & $\begin{array}{c}\text { Sangat } \\
\text { Tinggi }\end{array}$ & Tinggi & Sedang & Rendah & $\begin{array}{c}\text { Sangat } \\
\text { Rendah }\end{array}$ & Total \\
\hline 1 akun & $0(0 \%)$ & $0(0 \%)$ & $7(8 \%)$ & $31(35 \%)$ & $51(57 \%)$ & $89(100 \%)$ \\
2 akun & $0(0 \%)$ & $0(0 \%)$ & $0(0 \%)$ & $4(57 \%)$ & $3(43 \%)$ & $7(100 \%)$ \\
$>2$ akun & $0(0 \%)$ & $0(0 \%)$ & $0(0 \%)$ & $2(50 \%)$ & $2(50 \%)$ & $4(100 \%)$ \\
\hline
\end{tabular}

Berdasarkan Tabel 3, hasil data menunjukkan bahwa sebagian besar mahasiswa memiliki jumlah akun online shop paling banyak 1 akun sebanyak 89 dari 100 mahasiswa dan mahasiswa yang memiliki 2 akun sebanyak 7 orang dan yang lebih dari 2 akun sebanyak 4 orang. Karakteristik jumlah akun online shop pada 1 akun dengan persentase tertinggi terdapat pada kategori sangat rendah yaitu $57 \%$ dan pada kategori rendah sebanyak 34\%, sedangkan pada 2 akun memiliki persentase tertinggi yaitu pada kategori rendah sebesar $57 \%$ dan kategori sangat rendah sebesar $43 \%$. Jumlah akun yang lebih dari 2 masuk dalam kaegori sangat rendah dan rendah dengan persentase masing-masing 50\% atau sebanyak 2 mahasiswa. Tidak terdapat akun dengan kategori sangat tinggi, tinggi dan sedang kecuali pada jumlah 1 akun yang memiliki persentase 8\% pada kategori pola hidup konsumtif sedang.

Di lingkungan mahasiswa Universitas Pendidikan Mandalika memperlihatkan bahwa peminat dalam menggunakan akun online tersebut sangat rendah. Hal ini diakibatkan tingkat keterpecayaan mahasiswa terhadap penjualnya sangat rendah (Firdayanti, 2012), karena pembelian melalui online memiliki resiko yang sangat besar dibandingkan dengan pembelian eceran biasa (Haekal \& Widjajanto, 2016).

Langkah berikutnya yaitu tabel pendugaan parameter model regresi logistik ordinal dengan bantuan software SPSS pada Tabel 4. 
Tabel 4. Hasil Estimasi Parameter.

\begin{tabular}{cccccc}
\hline \hline Variabel & Kategori & Koefisien & $\begin{array}{c}\text { Standar } \\
\text { Error }\end{array}$ & $\operatorname{Exp}(\beta)$ & P-value \\
\hline $\begin{array}{c}\text { Pola hidup } \\
\text { konsumtif }(Y)\end{array}$ & Konstanta $1\left(y_{1}\right)$ & $-2,683$ & 1,053 & & 0,011 \\
& Konstanta $2\left(y_{2}\right)$ & $-0,324$ & 0,997 & & 0,754 \\
Asal daerah & Kota Mataram $\left(X_{1,1}\right)$ & $-0,597$ & 0,587 & 0,550 & 0,310 \\
& $\quad$ Luar Kota & 0 &. &. &. \\
Mataram $\left(X_{1,2}\right)$ & & & & \\
online shop & 1 akun $\left(X_{2,1}\right)$ & $-2,874$ & 1,052 & 0,056 & 0,006 \\
& 2 akun $\left(X_{2,2}\right)$ & $-2,543$ & 1,258 & 0,078 & 0,043 \\
& $>2$ akun $\left(X_{2,3}\right)$ & 0 &. &. &. \\
\hline
\end{tabular}

Dari lima kategori, mahasiswa masuk dalam tiga kategori sedang, rendah dan sangat rendah. Tidak ada mahasiswa yang masuk dalam kategori tinggi dan sangat tinggi. Jadi hanya tiga kategori $Y$ yang dapat terbaca pada tabel estimasi. Tabel 4 menjelaskan bahwa ada dua nilai konstanta yang muncul dari lima kategori variable $Y$. Apabila terdapat tiga kategori $Y$ pada tabel estimator maka ada dua model logit yang muncul (Setyawati, Korida \& Febrilia, 2020). Hal ini karena pada dua kategori pada variable $\mathrm{Y}$ tidak ada mahasiswa yang masuk ke dalam kategori tersebut, sehingga secara otomatis software hanya membaca tiga variable yang berdampak pada munculnya dua konstanta. Oleh karena hanya ada dua konstanta yang dihasilkan, maka model logit yang nantinya terbentuk juga hanya dua. Tabel estimator menyajikan koefisien, standar error koefisien, nilai $\operatorname{Exp}(\beta)$ atau disebut juga odds ratio dan P-value dari semua variabel. Odds ratio asal daerah mahasiswa dari kota mataram adalah 0,050 , yang menyatakan bahwa mahasiswa yang asal daerahnya memiliki pengaruh pola hidup konsumtif 0,050. Sedangkan variabel jumlah akun nilai odds ratio yang memiliki 2 jumlah akun yaitu sebesar 0,078. Sebelum membahas lebih jauh mengenai hasil estimasi parameter pada tabel ini, akan disajikan terlebih dulu hasil uji kecocokan model pada Tabel 5.

Tabel 5. Uji Kecocokan Model Regresi Logistik Ordinal.

\begin{tabular}{ccccc}
\hline \hline & $\begin{array}{c}\text { Chi } \\
\text { Square }\end{array}$ & Df & $\begin{array}{c}\text { P- } \\
\text { value }\end{array}$ & Keputusan \\
\hline Deviance & 5 & 6 & 0,384 & $\mathrm{H}_{0}$ diterima \\
\hline
\end{tabular}

Tabel 5 menjelaskan bahwa nilai $P=0,384>0,05$, maka $\mathrm{H}_{0}$ diterima, yang artinya daerah asal berpengaruh terhadap pola hidup konsumtif . Artinya bahwa model yang dihasilkan sudah cocok secara signifikan.

Hipotesis yang digunakan dalam mengambil keputusan Tabel 6 yaitu sebagai berikut.

$\mathrm{H}_{0}: \beta_{1}=\beta_{2}=0$

$\mathrm{H}_{1}$ : Minimal ada satu $\beta_{1} \neq 0, i=1,2$ 
Tabel 6. Uji Serentak Parameter Model dengan Menggunakan Likelihood Ratio.

\begin{tabular}{llllll}
\hline \hline Model & G2 & Chi Square & df & P-value & Keputusan \\
\hline Final & 22,640 & 9,090 & 3 & 0,028 & $\mathrm{H}_{0}$ ditolak \\
\hline
\end{tabular}

Kemudian didapatkan nilai $G 2>X(0,05 ; 3)=7,815$ yang berarti $\mathrm{H}_{0}$ ditolak sehingga terdapat satu parameter yang signifikan. Hal ini sama dengan $P-$ value $=$ $0,028<0,05$. Oleh karena minimal ada satu parameter yang nilainya tidak sama dengan nol, maka uji harus dilanjutkan pada pengujian parsial. Uji parsial digunakan untuk melihat akibat dari masing-masing variabel prediktor dengan variabel respon (Tampil, Komaliq, \& Langi, 2017). Uji ini menggunakan data pada Tabel 4 dengan mengamati nilai P-value masing-masing varabel prediktor. Hipotesis yang digunakan adalah sebagai berikut.

$$
\begin{aligned}
& \mathrm{H}_{0}: \beta_{j}=0 \\
& \mathrm{H}_{1}: \beta_{j} \neq 0, j=1,2
\end{aligned}
$$

Berdasarkan nilai P-value, variabel yang signifikan adalah yang memiliki nilai $P$ value $<0,05$ adalah $\left(X_{2,1}\right)$ dan $\left(X_{2,2}\right)$. Berikut model logit yang di dapatkan.

$$
\begin{aligned}
& \operatorname{Logit}\left(y_{1}\right)=\log \left(\frac{y_{1}}{1-y_{1}}\right)=-2,683+(-2,874) X_{2,1}+(-2,543) X_{2,2} \\
& \operatorname{Logit}\left(y_{2}\right)=\log \left(\frac{y_{2}}{1-y_{2}}\right)=-0,324+(-2,874) X_{2,1}+(-2,543) X_{2,2}
\end{aligned}
$$

\section{Kesimpulan}

Dari hasil penelitian dapat disimpulkan pola hidup konsumtf mahasiswa Universitas Mandalika Mataram berdasarkan hasil analisis dipengaruhi oleh banyaknya akun online shop yang digunakan, sedangkan asal daerah tidak berpengaruh. Karekteristik dari banyaknya akun mahasiswa adalah sebagian besar menggunakan 1 akun yaitu 89 dari 100 mahasiswa.

\section{Pustaka}

Astuti, E. D. (2013). Perilaku konsumtif dalam membeli barang pada ibu rumah tangga di Kota Samarinda. E-Jurnal Psikologi, 1(2), 148-156.

Dewi, N., \& Rusdarti, R. (2017). Pengaruh Lingkungan Keluarga, Teman Sebaya, Pengendalian Diri dan Literasi Keuangan Terhadap Perilaku Konsumtif Mahasiswa. Journal of Economic Education, 6(1), 29-35.

Febrilia B. R. A., Rahayu S., \& Korida B. D. (2019). Ordinal Logistic Regression Analysis of Factors Affecting the Length of Student Study. Jurnal Matematika "MANTIK\&quot; , 5(1), 28-34. 
Fitriah, W. W., Mashuri, M., \& Irhamah, I. (2012). Faktor-Faktor yang mempengaruhi keparahan korban Kecelakaan lalu lintas di kota Surabaya dengan pendekatan bagging regresi logistik ordinal. Jurnal sains dan seni ITS, 1(1), D253-D258.

Fatonah, L., Sanapiah, S., \& Febrilia, B. R. A. (2017). Regresi Logistik Ordinal (Studi Kasus Faktor yang Mempengaruhi Tingkat Stres Mahasiswa dalam Menyelesaikan Skripsi). Media Pendidikan Matematika, 5(2), 146-159.

Firdayanti, R. (2012). Persepsi risiko melakukan e-Commerce dengan kepercayaan konsumen dalam membeli produk fashion online. Journal of Social and Industrial Psychology, 1(1).

Gumulya, J., \& Widiastuti, M. (2013). Pengaruh konsep diri terhadap perilaku konsumtif mahasiswa Universitas Esa Unggul. Jurnal Psikologi Esa Unggul, 11(01), 126900.

Haekal, A., \& Widjajanta, B. (2016). Pengaruh kepercayaan dan persepsi risiko terhadap minat membeli secara online pada pengunjung website classifieds di inonesia. Journal of Business Management Education (JBME), 1(1), 183-195.

Kaplan, A. M., \& Haenlein, M. (2010). Users of the world, unite! The challenges and opportunities of Social Media. Business horizons, 53(1), 59-68.

Miranda, S., \& Lubis, E. E. (2017). Pengaruh Instagram Sebagai Media Online Shopping Fashion Terhadap Perilaku Konsumtif Mahasiswi Fakultas Ilmu Sosial Dan Ilmu Politik Universitas Riau (Doctoral dissertation, Riau University).

Novitasani, L. (2014). Perubahan Gaya Hidup Konsumtif Pada Mahasiswa Urban di UNESA. Paradigma, 2(3), 1-7.

Sari, C. A. (2015). Perilaku berbelanja online di kalangan mahasiswi antropologi Universitas Airlangga (Doctoral dissertation, UNIVERSITAS AIRLANGGA).

Sari, N. (2017). Hubungan Antara Gaya Hidup Hedonis dan Perilaku Konsumtif Dengan Perilaku Melanggar Peraturan Etika Berbusana Mahasiswa Pendidikan IPS FIS UNY. SOCIAL STUDIES, 6(5), 534-546.

Setyawati, D. U., Korida, B. D., \& Febrilia, B. R. A. (2020). Analisis Regresi Logistik Ordinal Faktor-Faktor yang Mempengaruhi IPK Mahasiswa. Jurnal Varian, 3(2), 65-72.

Suminar, E., \& Meiyuntari, T. (2015). Konsep diri, konformitas dan perilaku konsumtif pada remaja. Persona: Jurnal Psikologi Indonesia, 4(02), 145-152.

Tampil, Y., Komaliq, H., \& Langi, Y. (2017). Analisis Regresi Logistik Untuk Menentukan Faktor-Faktor Yang Mempengaruhi Indeks Prestasi Kumulatif (IPK) 
Mahasiswa FMIPA Universitas Sam Ratulangi Manado. d'CARTESIAN, 6(2), 56-62.

Zaman, S. (2017). Pola Konsumtif Masyarakat Urban dalam Perspektif Semiotik dan Budaya. Paradigma Jurnal Kajian Budaya, 7(1). 
